\title{
SYNTHESIS OF NOVEL 2-AMINO-5-ARYLAZOTHIAZOL DERIVATIVES AND THEIR BIOLOGICAL IMPACTS: ASSESSMENT OF TOXICITY AND ANTIOXIDANT ENZYME ACTIVITIES
}

\author{
Mohamed E. Khalifa ${ }^{1,2^{*}}$, Mahmoud A. Mohamed ${ }^{1,3}$, Noura H. AlShehri ${ }^{1,4}$ \\ ${ }^{1}$ Department of Chemistry, Faculty of Science, Taif University, Taif 21974, KSA \\ ${ }^{2}$ Department of Chemical Engineering, Higher Institute for Engineering and Technology, \\ New Damietta, Egypt \\ ${ }^{3}$ Department of Biochemistry, Faculty of Agriculture, Cairo University, Giza, Egypt \\ ${ }^{4}$ Department of Chemistry, Faculty of Science, King Khaled University, Bisha, KSA \\ *mohamedezzat200@hotmail.com
}

A reactivity study of both the amino group and the aryl substituent of a newly synthesized 2amino-5-(4-acetylphenylazo)-thiazole compound and its derivatives via various electrophilic reagents was performed to obtain new bioactive chalcone, imine, and pyrazole-thiazolidine derivatives. The synthesized compounds were chemically elucidated by analytical and spectral methods, and biologically evaluated in vitro and in vivo for their toxicity and antioxidant activity based on liver function enzymes.

Keywords: 2-aminothiazole; chalcone; imine; pyrazole; azo coupling; biological activities

\section{СИНТЕЗА НА НОВИ ДЕРИВАТИ НА 2-АМИНО-5-АРИЛТИАЗОЛ И НИВНА БИОЛОШКА АКТИВНОСТ: ПРОЦЕНА НА НИВНАТА ТОКСИЧНОСТ И АНТИОКСИДАТИВНА ЕНЗИМСКА АКТИВНОСТ}

\begin{abstract}
Извршено е испитување како на аминогрупата така и на арилсупституентот на ново синтетизирано соедиенние на 2-амино-5-(4-ацетилфенилазо)-тиазол и неговите деривати преку разни електрофилни реагенси за да се добијат нови биоактивни халконски, имински и пиразолтиазолидински деривати. Синтетизираните соединенија беа идентификувани преку аналитички и спектрални методи, а потоа беа и биолошки евалуирани in vitro и in vivo за нивната токсичност и антиоксидативна активност преку ензими од црниот дроб.
\end{abstract}

Клучни зборови: 2-аминотиазол; халкон; имин; пиразол; азоспарување; биолошка активност

\section{INTRODUCTION}

Azo compounds are of great importance due to their versatile application in various fields, such as the dyeing of textile fibers, coloring of different materials, biomedical studies, and advanced applications in organic synthesis [1-4]. In continuation of our previous work [5-8] on the synthesis of $\mathrm{S} / \mathrm{N}$ heterocyclic azo compounds with different applications, such as dyeing polyester fabrics and bioactive function, the present work describes the synthesis of several new $\mathrm{S} / \mathrm{N}$ heterocyclic mono azo compounds based on the 2-aminothiazole moiety, and their applications as biologically active materials. Diverse biological activities have been found to be associated with thiazolidine derivatives, including anesthetic [3], antiviral [4], antimicrobial [9], bactericidal [10], anti-inflammatory [11], fungicidal [12,13], and anticonvulsant [14-16] properties. It is well known that 2-aminothiazole can exhibit amino-imino tautomeric configurations in nature, and the amino configuration is the predominant tautomer [17]. Considering the reactivity of 2-aminothiazoles and their enormous biological 
importance, the chemical and biological study of selected 5-arylazo-2-aminothiazole and its various derivatives is a hot and interesting topic and is focus of our research.

\section{EXPERIMENTAL}

\subsection{Materials and methods}

All chemicals and reagents used were of analytical grade or were chemically pure, and were supplied by Sigma Aldrich Co. (Germany). All kits for biochemical parameters were supplied by Diagnostic Company (UK). Elemental analyses (C, $\mathrm{H}, \mathrm{N}$ ) were conducted using the Perkin-Elmer 2400 Analyzer, series II (Perkin Elmer Co., Shelton, UK). All of the melting points (uncorrected) are in ${ }^{\circ} \mathrm{C}$ and were measured using a Stuart SMP 20 melting point apparatus (Bibby Scientific Limited, Staffordshire, UK). The infrared spectra were recorded on a Perkin Elmer Alpha platinum-ATR spectrometer, and the ${ }^{1} \mathrm{H}$ NMR and ${ }^{13} \mathrm{C}$ NMR spectra were measured on a Bruker WP 300 (Bruker, MA, USA) using trimethylsilane (TMS) as an internal standard. All of the microanalyses and spectral analyses were performed by the Micro Analytical Centers of Taif (IR, CHN) and King AbdelAziz Universities $\left({ }^{1} \mathrm{H}\right.$ NMR, ${ }^{13} \mathrm{C}$ NMR), Kingdom of Saudi Arabia. Mass spectra were recorded on a Finnigan MAT 212 instrument (Micro Analytical Center, Faculty of Science, Mansoura University, Egypt). Male albino rats $(180 \pm 10 \mathrm{~g})$ were providedby the Animal Science Department (Faculty of Agriculture, Cairo University, Egypt) and the biological tests were performed by the Biotechnology Unit (Faculty of Agriculture, Cairo University, Egypt). Methods of biological assays are described in detail in the attached supplementary file $\mathrm{S} 1$.

\subsection{Synthesis}

\subsubsection{Synthesis of 2-amino-5-(4-acetylphenylazo)- thiazole 3}

The corresponding aryl diazonium chloride was prepared by adding cold sodium nitrite solution (10 mmol, $0.69 \mathrm{~g})$ in $\mathrm{H}_{2} \mathrm{O}(15 \mathrm{ml})$ to a cold suspension of 4 -aminoacetophenone $2(10 \mathrm{mmol}$, $1.35 \mathrm{~g})$ in concentrated $\mathrm{HCl}(4 \mathrm{ml})$ with stirring. To a cold solution of 2-aminothiazole $1(10 \mathrm{mmol}$, $1 \mathrm{~g})$ in ethanol $(20 \mathrm{ml})$ and sodium acetate $(20$ mmol, $1.6 \mathrm{~g}$ ), a cold aqueous solution from the corresponding aryl diazonium chloride was added dropwise with stirring at $-5{ }^{\circ} \mathrm{C}$ for 2 hours. The solid products obtained were filtered, washed with water followed by cold ethanol, and then dried. The obtained product was recrystallized from ethanol to give the 2-amino-5-(4-acetylphenylazo)thiazole 3.

Brown solid, yield: $73 \%$; m.p. $153-154^{\circ} \mathrm{C}$. IR $\left(\bar{v} / \mathrm{cm}^{-1}\right): 3358,3244\left(\mathrm{NH}_{2}\right), 1668(\mathrm{C}=\mathrm{O}) .{ }^{1} \mathrm{H}$ NMR (DMSO- $\left.d_{6}\right)(\delta / \mathrm{ppm}): 2.45\left(\mathrm{~s}, 3 \mathrm{H}, \mathrm{COCH}_{3}\right)$, $6.90\left(\mathrm{~s}, 1 \mathrm{H}\right.$, thiazole $\left.\mathrm{C}_{4}-\mathrm{H}\right), 7.50(\mathrm{~d}, 2 \mathrm{H}, \mathrm{Ar}-\mathrm{H})$, 7.85 (d, 2H, Ar-H), 8.15 (s, 2H, NH $\left.{ }_{2}\right) .{ }^{13} \mathrm{C}$ NMR (300 MHz, DMSO, TMS): $\delta 199.67\left(\mathrm{COCH}_{3}\right)$, $169.35\left(\mathrm{C}-\mathrm{NH}_{2}\right), 162.17,147.23,108.21$ (thiazole C) and 136.74, 133.12, 128.72, 128.80, 128.72 . MS (M+ $\left.{ }^{+} ; \mathrm{EI}\right): \mathrm{m} / \mathrm{z}=246(34.7 \%), 238(7.1 \%), 203$ (7.8\%), 152 (7.1\%), $147(12.9 \%), 135(18.5 \%)$, 129 (31.4\%), $120(33.3 \%), 100 \quad(25.5 \%), 71$ (23.2\%), 57 (36.5\%), 44 (100.0\%). Anal. calcd. for $\mathrm{C}_{11} \mathrm{H}_{10} \mathrm{~N}_{4} \mathrm{OS}$ (mol. wt.: 246.29): C, 53.64; H, 4.09; N, 22.75. Found: C, 53.49; H, 4.17; N, 22.81.

\subsubsection{Synthesis of 2-acetylamino-5-(4- acetylphenylazo)-thiazole 4}

A mixture of 2-amino-5-(4-acetylphenylazo)thiazole 3 (20 mmol, $4.9 \mathrm{~g}$ ) and acetic anhydride (10 $\mathrm{ml})$ was heated in a water bath at $100{ }^{\circ} \mathrm{C}$ for 2 hours. The reaction mixture was allowed to cool at room temperature, and was then recrystallized from ethanol to obtain the corresponding 2- $(N-$ acetylamino)-5-(4-acetylphenylazo)-thiazole 4.

Brown solid, yield: $52 \%$; m.p. $178-179{ }^{\circ} \mathrm{C}$. IR $\left(\bar{v} / \mathrm{cm}^{-1}\right): 3164(\mathrm{NH}), 1682(\mathrm{C}=\mathrm{O}), 1665$ $(\mathrm{C}=\mathrm{O}) .{ }^{1} \mathrm{H}$ NMR $\left(\mathrm{DMSO}-d_{6}\right)(\delta / \mathrm{ppm}): 2.25$ (s. $3 \mathrm{H}$, $\left.\mathrm{CH}_{3}\right), 2.45\left(\mathrm{~s}, 3 \mathrm{H}, \mathrm{COCH}_{3}\right), 6.90\left(\mathrm{~s}, 1 \mathrm{H}, \mathrm{C}_{4}-\right.$ thiazole $-\mathrm{H}), 7.45(\mathrm{~d}, 2 \mathrm{H}, \mathrm{Ar}-\mathrm{H}), 7.85(\mathrm{~d}, 2 \mathrm{H}, \mathrm{Ar}-$ $\mathrm{H}), 11.15(\mathrm{~s}, 1 \mathrm{H}, \mathrm{NH}) .{ }^{13} \mathrm{C}$ NMR $(300 \mathrm{MHz}$, DMSO, TMS): $\delta 199.77\left(\mathrm{COCH}_{3}\right), 168.91(\mathrm{C}-$ $\mathrm{NH}), 162.74,147.11,108.01$ (thiazole C) and 136.81, 133.11, 128.68, 128.70, 128.68. MS $\left(\mathrm{M}^{+}\right.$; $\mathrm{EI}): \mathrm{m} / z=288(22.6 \%), 245(12.2 \%), 223(15.7 \%)$, $120 \quad(44.8 \%), \quad 100 \quad(25.5 \%), \quad 77 \quad(11.6 \%), 44$ (100.0\%). Anal. calcd. for $\mathrm{C}_{13} \mathrm{H}_{12} \mathrm{~N}_{4} \mathrm{O}_{2} \mathrm{~S}$ (mol. wt.: 288.32): C, 54.15; H, 4.20; N, 19.43. Found: C, $54.02 ; \mathrm{H}, 4.28 ; \mathrm{N}, 19.40$.

\subsubsection{Synthesis of 2-benzoylamino-5-(4- acetylphenylazo)-thiazole 5}

A mixture of 2-amino-5-(4-acetylphenylazo)thiazole 3 ( $3 \mathrm{mmol}, 0.74 \mathrm{~g}$ ) and benzoyl chloride (3 mmol, $0.35 \mathrm{ml}$ ) was stirred in $15 \mathrm{ml}$ pyridine at room temperature. The reaction mixture was diluted with a solution of sodium acetate and filtered off. The 2-benzoylamino-5-(4-acetylphenylazo)-thiazole 5 obtained was dried and recrystallized from an ethanol/dimethyl formamide (DMF) mixture. 
Brown solid; yield: 53\%; m.p.: $210-212{ }^{\circ} \mathrm{C}$. $\operatorname{IR}\left(\bar{v} / \mathrm{cm}^{-1}\right): 3147(\mathrm{NH}), 1675\left(\mathrm{COCH}_{3}\right)$ and 1662 $(\mathrm{COPh}) \mathrm{cm}^{-1} .{ }^{1} \mathrm{H}$ NMR $\left(\mathrm{CF}_{3} \mathrm{COOD}\right): \delta / \mathrm{ppm}=2.57$ (s, 3H, $\left.\mathrm{CH}_{3}\right), 7.26-7.90$ (m, 9H, Ar-H), 8.16 (s, $1 \mathrm{H}, \mathrm{C}_{4}$-thiazole-H). ${ }^{13} \mathrm{C}$ NMR (300 MHz, DMSO, TMS): $\delta 199.81\left(\mathrm{COCH}_{3}\right), 164.83(\mathrm{C}-\mathrm{NH}), 162.80$, 147.11, 108.08 (thiazole C) and 136.78, 133.13, $127.47,127.48,128.88,128.80,128.88,128.90$, 128.89. MS ( $\left.\mathrm{M}^{+} ; \mathrm{EI}\right): \mathrm{m} / z=350(61.3 \%), 245$ (19.7\%), 203 (27.7\%), 120 (73.6\%), 77 (100.0\%). Anal. calcd. for $\mathrm{C}_{18} \mathrm{H}_{14} \mathrm{~N}_{4} \mathrm{O}_{2} \mathrm{~S}$ (mol. wt.: 350.39): C, 61.70; H, 4.03; N, 15.99. Found: C, 61.48; H, $4.17 ; \mathrm{N}, 15.84$.

\subsubsection{Synthesis of 2-chloroacetylamino-5-(4- acetylphenylazo)-thiazole 6}

A mixture of 2-amino-5-(4-acetylphenylazo)thiazole 3 ( $3 \mathrm{mmol}, 0.74 \mathrm{~g}$ ) in $10 \mathrm{ml} \mathrm{DMF}$ and chloroacetyl chloride $(3 \mathrm{mmol}, 0.34 \mathrm{ml}$ ) was stirred in the presence of $3 \mathrm{ml}$ triethylamine (TEA) for 4 hours. The reaction mixture was poured onto ice-cold water and filtered off to produce the chloroacetyl amino derivative 6. The collected product was dried and recrystallized from an ethanol/DMF mixture.

Brown solid; yield: $76 \%$; m.p.: $132-134{ }^{\circ} \mathrm{C}$. IR $\left(\bar{v} / \mathrm{cm}^{-1}\right): 3172(\mathrm{NH}), 1684(\mathrm{C}=\mathrm{O})$ and 1670 $(\mathrm{C}=\mathrm{O}$, acetyl $) \mathrm{cm}^{-1} \cdot{ }^{1} \mathrm{H}$ NMR $\left(\mathrm{CF}_{3} \mathrm{COOD}\right)$ : $\delta / \mathrm{ppm}=2.62\left(\mathrm{~s}, 3 \mathrm{H}, \mathrm{CH}_{3}\right), 4.11\left(\mathrm{~s}, 2 \mathrm{H}, \mathrm{CH}_{2}\right), 7.26$ (d, 2H, Ar-H), 7.78 (d, 2H, Ar-H), 8.07 (s, 1H, C4thiazole-H). ${ }^{13} \mathrm{C}$ NMR (300 MHz, DMSO, TMS): $\delta$ $199.78\left(\mathrm{COCH}_{3}\right), 165.43(\mathrm{C}-\mathrm{CONH}), 162.79$, 147.01, 108.10 (C-thiazole ring), and 136.80, $128.69,128.70,128.80,128.82$. MS $\left(\mathrm{M}^{+} ; \mathrm{EI}\right): \mathrm{m} / z$ $=322(3.3 \%), 238(5.9 \%), 223(7.3 \%), 196$ (11.85\%), 120 (13.0\%), 77 (9.5\%), 44 (100.0\%). Anal. calcd. for $\mathrm{C}_{13} \mathrm{H}_{11} \mathrm{~N}_{4} \mathrm{O}_{2} \mathrm{SCl}$ (mol. wt.: 322.77): C, 48.37; H, 3.44; N, 17.36. Found: C, 48.49; H, $3.48 ; \mathrm{N}, 17.27$.

\subsubsection{General procedure for the synthesis of the chalcones $(8 a-c)$ and the chalcone - imine derivatives $\mathbf{9 a}-\boldsymbol{c}$}

A mixture of the appropriate aromatic aldehydes $7 \mathbf{a}-\mathbf{c}(5 \mathrm{mmol})$ and compound 3 or 4 (1 mmol, $2.46 \mathrm{~g}$, and/or5 mmol, $1.44 \mathrm{~g}$, respectively) dissolved in ethanol $(50 \mathrm{ml})$ was added slowly to an aqueous solution of sodium hydroxide $(12 \mathrm{mmol}$, $0.48 \mathrm{~g}$, and/or $6 \mathrm{mmol}, 0.24 \mathrm{~g}$, respectively) in water $(10 \mathrm{ml})$. The reaction mixture was stirred at $20-25$ ${ }^{\circ} \mathrm{C}$ for $4 \mathrm{hrs}$. The solid product obtained was washed with cold water and recrystallized from ethanol to give 8a-c and 9a-c derivatives, respectively.
$N$-\{5-[\{4-[3-Phenylprop-2-enoyl]phenyl\}diazenyl]1,3-thiazol-2-yl \}acetamide 8a. Brown solid; yield: $43 \%$; m.p.: $>300{ }^{\circ} \mathrm{C}$. IR $\left(\bar{v} / \mathrm{cm}^{-1}\right): 3153(\mathrm{NH})$, $1672\left(\mathrm{NHCOCH}_{3}\right)$ and $1659(\underline{\mathrm{COCH}}=\mathrm{CH}) \mathrm{cm}^{-1}$. ${ }^{1} \mathrm{H}$ NMR $\left(\mathrm{CDCl}_{3} / \mathrm{CF}_{3} \mathrm{COOD}\right): \delta / \mathrm{ppm}=2.25(\mathrm{~s}$, $\left.3 \mathrm{H}, \mathrm{CH}_{3}\right), 7.21-7.90(\mathrm{~m}, 11 \mathrm{H}, \mathrm{Ar}-\mathrm{H}$ and two olefinic protons $\mathrm{CH}=\mathrm{CH}), 8.05\left(\mathrm{~s}, 1 \mathrm{H}, \mathrm{C}_{4}\right.$-thiazole- $\left.\mathrm{H}\right) .{ }^{13} \mathrm{C}$ NMR (300 MHz, DMSO, TMS): $\delta 189.71$ (CO), 168.83 (C-CONH), 162.80, 147.03, 108.08 (Cthiazole ring), $145.18,121.33(\mathrm{C}=\mathrm{C}), 137.80,134.52$, 135.22, 129.87, 129.88, 129.27, 129.28, 128.66, 128.67, 128.04, 126.39, 126.40. MS $\left(\mathrm{M}^{+}+\mathrm{H}\right.$; CI isobutane): $\mathrm{m} / \mathrm{z}=377(100.0 \%)$. Anal. calcd. for $\mathrm{C}_{20} \mathrm{H}_{16} \mathrm{~N}_{4} \mathrm{O}_{2} \mathrm{~S}$ (mol. wt.: 376.43): $\mathrm{C}, 63.81 ; \mathrm{H}, 4.28$; N, 14.88. Found: C, 63.64; H, 4.13; N, 14.71.

$N$-\{5-[\{4-[(3-(1H-Indol-3-yl)prop-2-enoyl]phenyl\}diazenyl]-1,3-thiazol-2-yl\}acetamide $8 b$. Brown solid; yield: $63 \%$; m.p.: $220^{\circ} \mathrm{C}$. IR $\left(\bar{v} / \mathrm{cm}^{-1}\right)$ : $3214(\mathrm{NH}), \quad 1678 \quad\left(\mathrm{NHCOCH}_{3}\right)$ and 1655 $(\mathrm{COCH}=\mathrm{CH}) \mathrm{cm}^{-1}$. ${ }^{1} \mathrm{H}$ NMR $\left(\mathrm{CDCl}_{3} / \mathrm{CF}_{3} \mathrm{COOD}\right)$ : $\delta / \mathrm{ppm}=2.25\left(\mathrm{~s}, 3 \mathrm{H}, \mathrm{CH}_{3}\right), 7.15-7.80(\mathrm{~m}, 10 \mathrm{H}, \mathrm{Ar}-$ $\mathrm{H}$ and two olefinic protons $\mathrm{CH}=\mathrm{CH}), 8.05(\mathrm{~s}, 1 \mathrm{H}$, $\mathrm{C}_{4}$-thiazole-H), 9.15 (s, $1 \mathrm{H}, \mathrm{C}_{2}$-pyrrol-H). ${ }^{13} \mathrm{C}$ NMR (300 MHz, DMSO, TMS): $\delta 189.73$ (CO), 168.91 (C-CONH), 162.78, 147.01, 108.04 (Cthiazole ring), 145.20, $121.38 \quad(\mathrm{C}=\mathrm{C}), 135.48$, $130.77,126.08,122.17,120.10,111.13,110.58$ (Cindole), 137.85, 134.44, 129.88, 129.86, 129.31, 129.30. MS $\left(\mathrm{M}^{+}+\mathrm{H}\right.$; CI iso-butane): $\mathrm{m} / \mathrm{z}=416$ (82.4\%). Anal. calcd. for $\mathrm{C}_{22} \mathrm{H}_{17} \mathrm{~N}_{5} \mathrm{O}_{2} \mathrm{~S}$ (mol. wt.: 415.47): C, 63.60; H, 4.12; N, 16.86. Found: C, 63.42; H, 3.98; N, 16.77 .

$\mathrm{N}$-\{5-[\{4-[3-(3-Methylthiophen-2-yl)prop-2-enoyl]phenyl\}-diazenyl]-1,3-thiazol-2-yl\}acetamide

8c. Brown solid; yield: $69 \%$; m.p.: $140-141{ }^{\circ} \mathrm{C}$. IR $\left(\bar{v} / \mathrm{cm}^{-1}\right): 3133(\mathrm{NH}), 1670\left(\mathrm{NHCOCH}_{3}\right)$ and 1662 $(\mathrm{COCH}=\mathrm{CH}) \mathrm{cm}^{-1} .{ }^{1} \mathrm{H}$ NMR $\left(\mathrm{CDCl}_{3} / \mathrm{CF}_{3} \mathrm{COOD}\right)$ : $\delta / \mathrm{ppm}=2.25\left(\mathrm{~s}, 3 \mathrm{H}, \mathrm{CH}_{3}\right), 2.40\left(\mathrm{~s}, 3 \mathrm{H}, \mathrm{CH}_{3}\right)$, 7.10-7.80 (m, 8H, Ar-H and two olefinic protons $\mathrm{CH}=\mathrm{CH}), 8.10$ (s, $1 \mathrm{H}, \mathrm{C}_{4}$-thiazole-H). ). ${ }^{13} \mathrm{C}$ NMR (300 MHz, DMSO, TMS): $\delta 189.68$ (CO), 168.90 (C-CONH), 162.80, 147.03, 107.97 (C-thiazole ring), 134.21, $127.39(\mathrm{C}=\mathrm{C}), 139.18,131.07$, 130.38, 126.11 (C-thiophene), 137.90, 134.47, 129.90, 129.89, 129.30, 129.28. MS ( $\left.{ }^{+} ; \mathrm{EI}\right): \mathrm{m} / \mathrm{z}$ $=396(8.1 \%), 144(95.9 \%), 116(34.2 \%), 97$ (20.3\%), 89 (20.3\%), 73 (100.0\%), 57 (33.3\%). Anal. calcd. for $\mathrm{C}_{19} \mathrm{H}_{16} \mathrm{~N}_{4} \mathrm{O}_{2} \mathrm{~S}_{2}$ (mol. wt.: 396.49): C, 57.56; H, 4.07; N, 14.13. Found: C, 57.34; H, $3.98 ; \mathrm{N}, 14.22$.

3-Phenyl-1-\{4-[2-\{[phenylmethylidene $]$ amino $\}-1,3-$ thiazol-5-yl)diazenyl]-phenyl\}prop-2-en-1-one 9a. Brown solid; yield: $41 \%$; m.p.: $>300{ }^{\circ} \mathrm{C}$. IR 
$\left(\bar{v} / \mathrm{cm}^{-1}\right): 1662(\underline{\mathrm{COCH}}=\mathrm{CH}), 1644(\mathrm{C}=\mathrm{N}) \mathrm{cm}^{-1}$. ${ }^{1} \mathrm{H}$ NMR $\left(\mathrm{CDCl}_{3} / \mathrm{CF}_{3} \mathrm{COOD}\right): \delta / \mathrm{ppm}=7.15-7.90$ (m, $16 \mathrm{H}, \mathrm{Ar}-\mathrm{H}$ and two olefinic protons $\mathrm{CH}=\mathrm{CH}$ ), $8.05\left(\mathrm{~s}, 1 \mathrm{H}, \mathrm{C}_{4}\right.$-thiazole-H), $8.25(\mathrm{~s}, 1 \mathrm{H}, \mathrm{N}=\mathrm{CH})$. ${ }^{13} \mathrm{C}$ NMR (300 MHz, DMSO, TMS): $\delta 189.71$ (CO), $160.12(\mathrm{C}=\mathrm{N}), 171.80,151.48,118.96(\mathrm{C}-$ thiazole ring), 144.21, $121.39 \quad(\mathrm{C}=\mathrm{C}), 137.92$, $135.16,134.51,129.90,129.89,129.30,129.28$, $128.71,128.70,128.00,126.34,126.33$. MS $\left(\mathrm{M}^{+}\right.$ $+\mathrm{H}$; CI iso-butane): $\mathrm{m} / \mathrm{z}=423(67.1 \%)$. Anal. calcd. for $\mathrm{C}_{25} \mathrm{H}_{18} \mathrm{~N}_{4} \mathrm{OS}$ (mol. wt.: 422.5): $\mathrm{C}, 71.07 ; \mathrm{H}$, 4.29; N, 13.26. Found: C, 70.88; H, 4.13; N, 13.08 .

1-\{4-[(2-\{[1H-Indol-3-ylmethylidene $]$ amino $\}-1,3-$ thiazol-5-yl)diazenyl]-phenyl\}-3-(1H-indol-3-yl) prop-2-en-1-one 9b. Brown solid; yield: 76\%; m.p.: $198-200{ }^{\circ} \mathrm{C}$. IR $\left(\bar{v} / \mathrm{cm}^{-1}\right): 3207(\mathrm{NH}), 1655$ $(\underline{\mathrm{COCH}}=\mathrm{CH}), \quad 1638 \quad(\mathrm{C}=\mathrm{N}) \quad \mathrm{cm}^{-1} .{ }^{1} \mathrm{H} \quad \mathrm{NMR}$ $\left(\mathrm{CDCl}_{3} / \mathrm{CF}_{3} \mathrm{COOD}\right): \delta / \mathrm{ppm}=7.15-7.80(\mathrm{~m}, 15 \mathrm{H}$, $\mathrm{Ar}-\mathrm{H}$ and two olefinic protons $\mathrm{CH}=\mathrm{CH}), 8.05$ (s, $1 \mathrm{H}, \mathrm{C}_{4}$-thiazole-H), $8.20(\mathrm{~s}, 1 \mathrm{H}, \mathrm{N}=\mathrm{CH}), 9.20(\mathrm{~s}$, $1 \mathrm{H}, \mathrm{C}_{2}$-pyrrol-H). ${ }^{13} \mathrm{C}$ NMR (300 MHz, DMSO, TMS): $\delta 189.70$ (CO), 171.65, 151.43, 118.64 (Cthiazole ring $), 145.19,126.38 \quad(\mathrm{C}=\mathrm{C}), 160.08$ $(\mathrm{C}=\mathrm{N}), 135.51,130.74,126.13,122.14,120.11$, 110.93, 102.28 (C-indole), 137.90, 134.43, 129.83, 129.81, 129.29, 129.28. MS $\left(\mathrm{M}^{+}+\mathrm{H}\right.$; CI isobutane): $\mathrm{m} / z=501(85.6 \%)$. Anal. calcd. for $\mathrm{C}_{29} \mathrm{H}_{20} \mathrm{~N}_{6} \mathrm{OS}$ (mol. wt.: 500.57): C, 69.58; H, 4.03; $\mathrm{N}, 16.79$. Found: C, 69.41; H, 3.87; N, 16.88 .

3-(3-Methylthiophen-2-yl)-1-\{4-[(2-\{[3-methylthiophen-2-yl)methylidene]-amino\}-1,3-thiazol-5-yl) diazenyl]phenyl\}prop-2-en-1-one 9c. Brown solid; yield: $39 \%$; m.p.: $186-187{ }^{\circ} \mathrm{C}$. IR $\left(\bar{v} / \mathrm{cm}^{-1}\right)$ : $1661(\mathrm{COCH}=\mathrm{CH}), 1641(\mathrm{CH}=\mathrm{N}) \mathrm{cm}^{-1} \cdot{ }^{1} \mathrm{H}$ NMR $\left(\mathrm{CDCl}_{3} / \mathrm{CF}_{3} \mathrm{COOD}\right): \delta / \mathrm{ppm}=2.40\left(\mathrm{~s}, 3 \mathrm{H}, \mathrm{CH}_{3}\right)$, $2.45\left(\mathrm{~s}, 3 \mathrm{H}, \mathrm{CH}_{3}\right), 7.10-7.80(\mathrm{~m}, 10 \mathrm{H}, \mathrm{Ar}-\mathrm{H}$ and two olefinic protons $\mathrm{CH}=\mathrm{CH}), 8.05\left(\mathrm{~s}, 1 \mathrm{H}, \mathrm{C}_{4}\right.$ thiazole-H), $8.30(\mathrm{~s}, 1 \mathrm{H}, \mathrm{N}=\mathrm{CH}) .{ }^{13} \mathrm{C}$ NMR $(300$ MHz, DMSO, TMS): $\delta 189.70$ (CO), 172.01, 150.98, 117.98 (C-thiazole ring), 134.17, 127.34 $(\mathrm{C}=\mathrm{C}), \quad 139.22, \quad 131.08, \quad 130.39, \quad 126.01 \quad(\mathrm{C}-$ thiophene), 137.97, 134.51, 129.90, 129.89, 129.27, 129.26. MS ( $\left.{ }^{+} ; \mathrm{EI}\right): \mathrm{m} / \mathrm{z}=462(5.7 \%), 253$ (10.3\%), 238 (20.4\%), 222 (12.4\%), $192(42.3 \%)$, 177 (33.9\%), 162 (52.2\%), 135 (61.4\%), 120 (100.0\%), 97 (23.9\%), 92 (39.3\%). Anal. calcd. for $\mathrm{C}_{23} \mathrm{H}_{18} \mathrm{~N}_{4} \mathrm{OS}_{3}$ (mol. wt.: 462.61): C, 59.71; H, 3.92; N, 12.11. Found: C, 59.56; H, 3.84; N, 11.98.

\subsubsection{General procedure for the preparation of pyrazole derivatives $\mathbf{1 0 a - c}$}

To a solution of appropriate chalcones $\mathbf{8 a}-\mathbf{c}$ (2mmol) in ethanol $(30 \mathrm{ml}), 80 \%$ hydrazine hydrate
( $5 \mathrm{mmol}, 0.3 \mathrm{ml}$ ) was added. The reaction mixture was refluxed for 6 hours, thenleft to cool to room temperature, and the formed solid product was filtered and washed with ethanol.

$N$-(5-\{[4-(5-Phenyl-4,5-dihydro-1 $H$-pyrazol-3-yl) phenyl]diazenyl\}-1,3-thiazol-2-yl)acetamide 10a. Brown solid; yield: $77 \%$; m.p.: $>300^{\circ} \mathrm{C}$. IR $\left(\bar{v} / \mathrm{cm}^{-1}\right): 3205,3164(\mathrm{NH}), 1675(\mathrm{C}=\mathrm{O})$ and 1635 $(\mathrm{C}=\mathrm{N}) \quad \mathrm{cm}^{-1} . \quad{ }^{1} \mathrm{H} \quad \mathrm{NMR} \quad\left(\mathrm{CDCl}_{3} / \mathrm{CF}_{3} \mathrm{COOD}\right)$ : $\delta / \mathrm{ppm}=2.20\left(\mathrm{~s}, 3 \mathrm{H}, \mathrm{CH}_{3}\right), 2.85(\mathrm{dd}, 1 \mathrm{H}, \mathrm{CH}), 3.20$ (dd, 1H, CH), 4.60 (t, 1H, CH), 7.10-7.80 (m, 9H, Ar-H), 8.10 (s, $1 \mathrm{H}, \mathrm{C}_{4}$-thiazole-H). ${ }^{13} \mathrm{C}$ NMR $(300$ MHz, DMSO, TMS): $\delta 168.90$ (C-CONH), 162.80 , 146.93, 108.01 (C-thiazole ring), 151.11, 49.13, 42.49 (C-pyrazole), 184.06, 143.45, 131.47, $129.91,129.89,129.20,129.21,128.55,127.03$, 126.76. MS $\left(\mathrm{M}^{+}+\mathrm{H}\right.$; CI iso-butane): $\mathrm{m} / \mathrm{z}=391$ (100.0\%). Anal. calcd. for $\mathrm{C}_{20} \mathrm{H}_{18} \mathrm{~N}_{6} \mathrm{OS}$ (mol. wt.: 390.46): C, 61.52; H, 4.65; N, 21.52. Found: C, $61.35 ; \mathrm{H}, 4.57 ; \mathrm{N}, 21.64$.

\section{$N$-\{5-[\{4-[5-(1H-Indol-3-yl)-4,5-dihydro-1H-pyra-} zol-3-yl]phenyl\}diazenyl]-1,3-thiazol-2-yl\}acetamide 10b. Brown solid; yield: 38\%; m.p.: $282-283{ }^{\circ} \mathrm{C}$. IR $\left(\bar{v} / \mathrm{cm}^{-1}\right): 3258,3214(\mathrm{NH}), 1675(\mathrm{C}=\mathrm{O})$ and $1645(\mathrm{C}=\mathrm{N}) \mathrm{cm}^{-1}$. ${ }^{1} \mathrm{H}$ NMR $\left(\mathrm{CDCl}_{3} / \mathrm{CF}_{3} \mathrm{COOD}\right)$ : $\delta / \mathrm{ppm}=2.20\left(\mathrm{~s}, 3 \mathrm{H}, \mathrm{CH}_{3}\right), 2.80(\mathrm{dd}, 1 \mathrm{H}, \mathrm{CH}), 3.35$ (dd, 1H, CH), $4.70(\mathrm{t}, 1 \mathrm{H}, \mathrm{CH}), 7.15-7.80(\mathrm{~m}, 8 \mathrm{H}$, Ar-H), 8.10 (s, 1H, C $4_{4}$ thiazole-H), 9.10 (s, 1H, C $2^{-}$ pyrrol-H). ${ }^{13} \mathrm{C}$ NMR (300 MHz, DMSO, TMS): $\delta$ 168.90 (C-CONH), 162.80, 146.93, 108.01 (Cthiazole ring), 151.11, 49.13, 42.49 (C-pyrazole), $184.06,143.45,131.47,129.91,129.89,129.20$, 129.21, 128.55, 127.03, 126.76. MS $\left(\mathrm{M}^{+}+\mathrm{H}\right.$; CI iso-butane): $\mathrm{m} / \mathrm{z}=430$ (100.0\%). Anal. calcd. for $\mathrm{C}_{22} \mathrm{H}_{19} \mathrm{~N}_{7} \mathrm{OS}$ (mol. wt.: 429.5): C, 61.52; H, 4.46; N, 22.83. Found: C, 61.42; H, 4.36; N, 22.68.

$N$-\{5-[\{4-[5-(3-Methylthiophen-2-yl)-4,5-dihydro$1 H$-pyrazol-3-yl]-phenyl\}diazenyl]-1,3-thiazol-2yl\}acetamide 10c. Brown solid; yield: 60\%; m.p.: 215-218 ${ }^{\circ} \mathrm{C}$. IR $\left(\bar{v} / \mathrm{cm}^{-1}\right): 3211(\mathrm{NH}), 1668(\mathrm{C}=\mathrm{O})$ and $1642(\mathrm{C}=\mathrm{N}) \mathrm{cm}^{-1} .{ }^{1} \mathrm{H}$ NMR $\left(\mathrm{CDCl}_{3} / \mathrm{CF}_{3} \mathrm{COOD}\right)$ : $\delta / \mathrm{ppm}=2.20\left(\mathrm{~s}, 3 \mathrm{H}, \mathrm{CH}_{3}\right), 2.45\left(\mathrm{~s}, 3 \mathrm{H}, \mathrm{CH}_{3}\right), 2.75$ $(\mathrm{dd}, 1 \mathrm{H}, \mathrm{CH}), 3.30(\mathrm{dd}, 1 \mathrm{H}, \mathrm{CH}), 4.75(\mathrm{t}, 1 \mathrm{H}, \mathrm{CH})$, 7.10-7.70 (m, 6H, Ar-H), 8.10 (s, 1H, C4-thiazoleH). ${ }^{13} \mathrm{C}$ NMR (300 MHz, DMSO, TMS): $\delta 168.88$ (C-CONH), 162.75, 147.04, 107.91 (C-thiazole ring), 151.09, 43.53, 41.74 (C-pyrazole), 133.91, 124.60, 124.09 (C-thiophene), 184.04, 131.11, 129.88, $129.86,129.20,129.21$. MS $\left(\mathrm{M}^{+} ; \mathrm{EI}\right): \mathrm{m} / \mathrm{z}=410$ (7.4\%), 236 (8.1\%), 213 (15.3\%), 185 (18.2\%), 149 (40.0\%), 129 (50.8\%), 111 (40.4\%), 97 (59.5\%), 83 (61.6\%), 77 (20.1\%), 57 (100.0\%). Anal. calcd. for $\mathrm{C}_{19} \mathrm{H}_{18} \mathrm{~N}_{6} \mathrm{OS}_{2}$ (mol. wt.: 410.52): C, 55.59; H, 4.42; N, 20.47. Found: C, 55.41; H, 4.37; N, 20.29. 


\subsection{Biological assays}

The potential antioxidant activities of the synthesized compounds were carried out using the 1,1-diphenyl-2-picrylhydrazyl (DPPH) radicalscavenging activity assay [13], and the percentage inhibition of the DPPH radical by the samples was calculated according to the following equation:

$$
\text { Inhibition } \%=\frac{A_{\mathrm{b}}-A_{\mathrm{a}}}{A_{\mathrm{b}}} \cdot 100
$$

$A_{\mathrm{b}}$ is the absorption of the blank sample $(t=0 \mathrm{~min})$ and $A_{\mathrm{a}}$ is the absorption of the tested compounds or standard substance solution $(t=30 \mathrm{~min})$.

The acute toxicity of the selected compounds $3,5,9 \mathrm{~b}$ and $10 \mathrm{c}$ based on in vitro antioxidant potential results was monitored in an animal model system by the $\mathrm{LD}_{50}$ value and biochemical analysis, including glutathione- $S$-transferase (GST) and lactic dehydrogenase (LDH) activities according to OECD guideline [14-16]. The toxicological effects were observed in terms of mortality, and are expressed as $\mathrm{LD}_{50}$ and the number of animals dying during the period was noted. Antioxidant activity, based on the in vitro antioxidant potential results, of the selected compounds $\mathbf{3 , 5 , 9 b}$ and $\mathbf{1 0 c}$ was determined in vivo. Male albino rats were quarantined and handled according to the institutional ethical guidelines and under the standard laboratory conditions as detailed in S1. For the enzyme activity measurements, glutathione-S-transferase (GST) is expressed in $\mu$ mol of glutathione conjugated with 1-chloro-2,4-dinitrobenzene $(C D N B)$ produced/mg protein/min [17], Super Oxide Dismutase (SOD) is expressed in units/mg protein [18], and glutathione reduced (GSH-Rd) levels in the liver and kidney tissues were determined according to the Ellman method [19] and the results are expressed in $\mathrm{mg} / \mathrm{g}$ protein. The protein levels were determined at $595 \mathrm{~nm}$ using Coomassie Brilliant Blue G-250 as a protein-binding dye, and bovine serum albumin (BSA) was used as a protein standard [20].
Each of the measurements described was carried out in three replicate experiments, and the results are recorded as mean \pm standard deviation. Significant differences were calculated at the level of $\mathrm{p} \leq 0.05$.

\section{RESULTS AND DISCUSSION}

\subsection{Chemistry}

The biological properties associated with the thiazolidine derivatives prompted us to synthesize new thiazolidine derivatives 4-10 using standard functional group transformation, and to study their in vitro and in vivo toxicity and antioxidant function.

Firstly, 2-aminothiazole 1 was allowed to couple with 4-aminoacetophenone $\mathbf{2}$ to form a new 2-amino-5-(4-acetylphenylazo)-thiazole $\mathbf{3}$ under mild basic conditions (Scheme 1). The chemical structure of $\mathbf{3}$ was confirmed by its analytical and spectral data. The IR spectrum of $\mathbf{3}$ revealed intense bands at 3358 and $3244 \mathrm{~cm}^{-1}\left(\mathrm{NH}_{2}\right)$, and $1668 \mathrm{~cm}^{-1}$ (CO, acetyl). The ${ }^{1} \mathrm{H}$ NMR spectrum of 3 displayed a singlet signal at $\delta 2.45 \mathrm{ppm}$ due to the methyl protons $\left(\mathrm{COCH}_{3}\right)$, a singlet at $\delta 6.90$ $\mathrm{ppm}$ due to the $\mathrm{C}_{4}$-thiazole proton, two doublet signals at $\delta 7.50 \mathrm{ppm}$ and $7.85 \mathrm{ppm}$ due to the aromatic protons, and a broad singlet at $\delta 8.15 \mathrm{ppm}$ due to $\mathrm{NH}_{2}$ protons. The molecular structure of the synthesized 2-amino-5-(4-acetylphenylazo)-thiazole 3 was confirmed by mass spectroscopy. The mass spectrum of $\mathbf{3}$ showed a molecular ion peak at $\mathrm{m} / \mathrm{z}$ $=246$ (intensity $34.7 \%$ ) corresponding to the molecular weight of the molecular formula $\mathrm{C}_{11} \mathrm{H}_{10} \mathrm{~N}_{4} \mathrm{OS}$.

The new 5-arylazo-2-aminothiazolidine $\mathbf{3}$ was investigated as the precursor compound of our study to explore its reactivity, where a series of chemical reactions were performed at the terminal amino and acetyl groups as shown in schemes 2-5. The reactivity of the thiazolyl amino group was detected via a series of custom reactions with various active carbonyl reagents (Scheme 2).<smiles>CC(=O)c1ccc(N=Nc2cnc(N)s2)cc1</smiles>

Scheme 1. Synthesis of 2-amino-5-(4-acetylphenylazo)-thiazole compound 3 


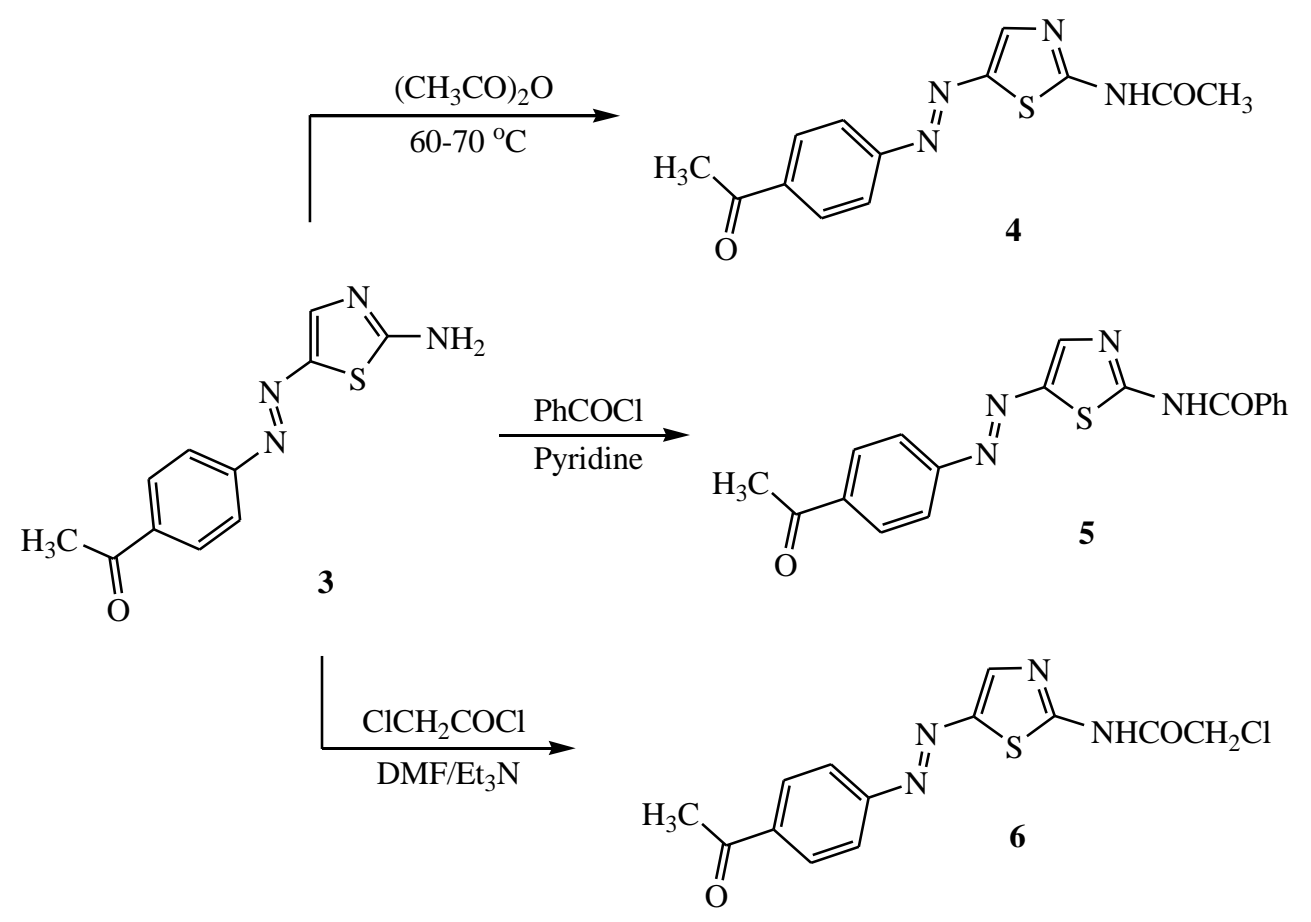

Scheme 2. Reactivity of amino groups towards various electrophilic reagents

As shown in scheme 2 , a convenient acetylation reaction of 2-amino-5-(4-acetylphenylazo)thiazole 3 by solvent-free acetylation with acetic anhydride at $60-70{ }^{\circ} \mathrm{C}$ afforded the $N$-acetylated product 4 . The chemical structure of 2 -acetylamino5-(4-acetylphenylazo)-thiazole 4 was confirmed by its analytical and spectral data. The IR spectrum revealed intense bands at $3164 \mathrm{~cm}^{-1}$ (NH stretching), and 1682 and $1665 \mathrm{~cm}^{-1}$ (two $\mathrm{C}=\mathrm{O}$ stretching bands). The ${ }^{1} \mathrm{H}$ NMR spectrum of $\mathbf{4}$ displayed two singlet signals at $\delta 2.25$ and $2.45 \mathrm{ppm}$ for two methyl protons, a singlet at $\delta 6.90$ for the $\mathrm{C}_{4}$-thiazole proton, two doublet signals at $\delta 7.45 \mathrm{ppm}$ and 7.85 ppm due to the aromatic protons, and a singlet signal at $\delta 11.15 \mathrm{ppm}$ for the NH proton. The electrophilic attack of the benzoyl cation towards the 2amino-5-(4-acetylphenylazo)-thiazole $\mathbf{3}$ in presence of pyridine and at room temperature yielded the benzoyl amino derivative 5. The synthesized 2-benzoylamino-5-(4-acetylphenylazo)-thiazole $\mathbf{5}$ was confirmed by its analytical and spectral data. The IR spectrum of $\mathbf{5}$ was characterized by the presence of strong absorption bands at $3147 \mathrm{~cm}^{-1}$ corresponding to $\mathrm{NH}$ (NHCOMe), at $1675 \mathrm{~cm}^{-1}$ corresponding to the $\mathrm{C}=\mathrm{O}$ stretching $\left(\mathrm{COCH}_{3}\right)$, and at $1662 \mathrm{~cm}^{-1}$ corresponding to the carbonyl group of the benzoyl function (COPh). The ${ }^{1} \mathrm{H}$ NMR spectrum of $\mathbf{5}$ in $\mathrm{CF}_{3} \mathrm{COOD}$ was characterized by the presence of a singlet peak at $\delta 2.57 \mathrm{ppm}$ corresponding to methyl protons, as well as multiplet peaks in the region $\delta$ 7.26-7.90 ppm corresponding to the aromatic protons, and a singlet signal at $\delta$ $8.16 \mathrm{ppm}$ corresponding to the $\mathrm{C}_{4}$-thiazole proton. A further reaction of the highly activated chloroacetyl chloride reagent with 2-amino-5-(4acetylphenylazo)-thiazole $\mathbf{3}$ under basic conditions using triethylamine (TEA) in the presence of dimethylformamide (DMF) was performed to produce the chloroacetyl amino derivative 6 . The chemical structure of 2-chloroacetylamino-5-(4acetylphenylazo)-thiazole $\mathbf{6}$ was elucidated by its analytical and spectral data. The IR spectrum of $\mathbf{6}$ revealed intense bands at $3172 \mathrm{~cm}^{-1}$ corresponding to $\mathrm{NH}(\mathrm{CONH})$, at $1684 \mathrm{~cm}^{-1}$ corresponding to the carbonyl of the $\mathrm{NHCOCH}_{2} \mathrm{Cl}$ function, and at 1670 $\mathrm{cm}^{-1}$ due to the carbonyl group of the acetyl function. The ${ }^{1} \mathrm{H}$ NMR spectrum of $\mathbf{6}$ displayed the singlet signal of methylene protons $\left(\mathrm{NHCOCH}_{2} \mathrm{Cl}\right)$ at $\delta 4.11 \mathrm{ppm}$ in addition to other signals at $\delta 2.62$ ppm (singlet for three protons, $\mathrm{CH}_{3}$ ), $\delta 7.26$ and $7.78 \mathrm{ppm}$ (two doublets for the aromatic protons), and a singlet signal at $\delta 8.07$ due to the $\mathrm{C}_{4}$-thiazole proton. On the other hand, the reactivity of the functionalized terminal acetyl groups was studied via Claisen-Schmidt condensation using aromatic and/or heterolytic aldehydes in alkaline medium [18-23]. Therefore, condensation of 2-acetylamino5-(4-acetylphenylazo)-thiazole 4 with an equimolar ratio of aromatic and/or heterocyclic aldehydes $\mathbf{7 a -}$ $\mathbf{c}$ in sodium hydroxide and water/ethanol medium led to the exclusive formation of chalcones $\mathbf{8 a}-\mathbf{c}$ (Scheme 3). 


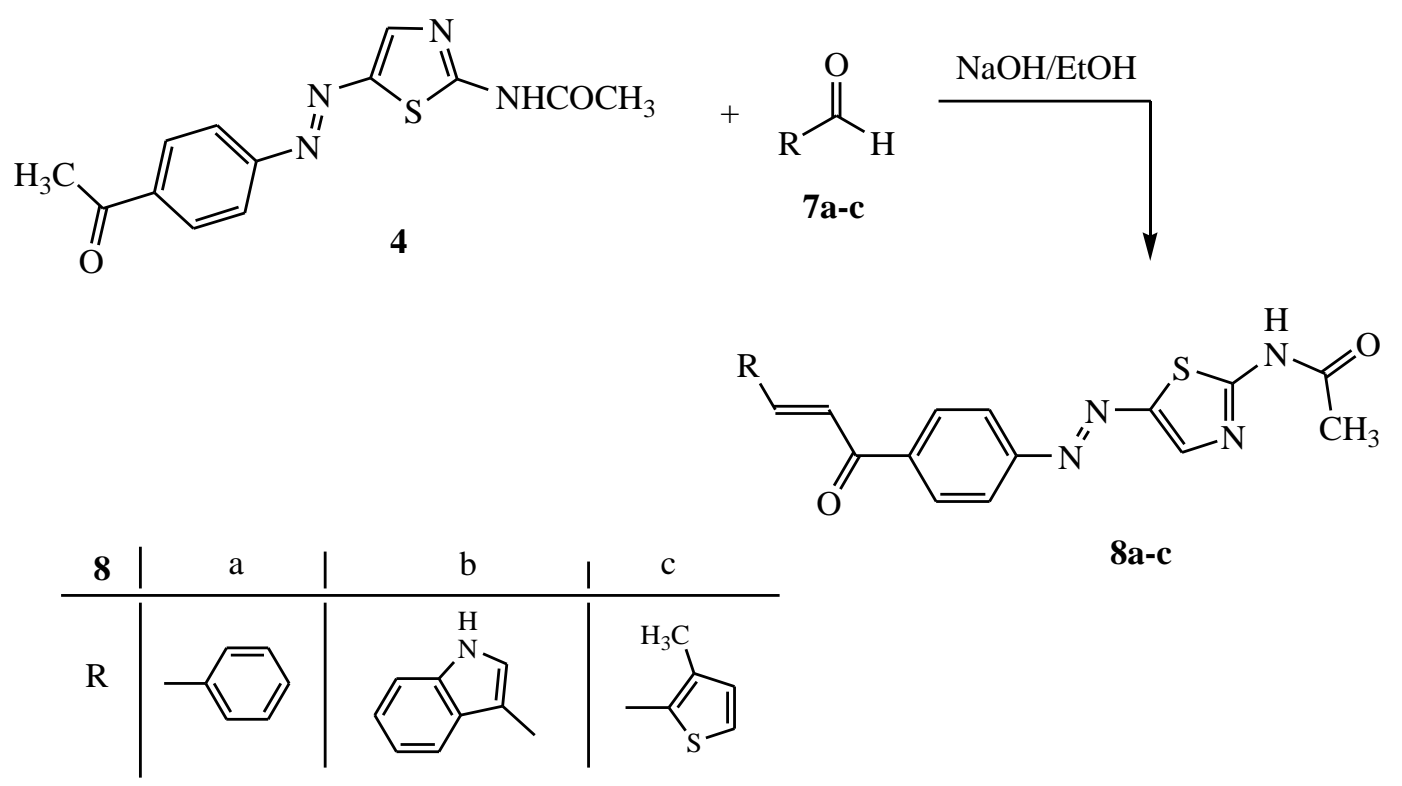

Scheme 3. Condensation reaction of 2-acetylamino-5-(4-acetylphenylazo)-thiazole 4 with an equimolar ratio of aromatic and/or heterolytic aldehydes $7 \mathbf{a}-\mathbf{c}$ to form chalcones $\mathbf{8 a}-\mathbf{c}$

The chemical structures of $N-\{5-\{4-[3-$ aryl(heteryl)prop-2-enoyl]phenyl \}diazenyl]-1,3-thiazol-2-yl \}acetamide derivatives 8a-c were confirmed by their elemental analyses and spectral data. The IR spectrum of 8a-c generally exhibited an intense band in the range $1655-1662 \mathrm{~cm}^{-1}$ for the acetyl carbonyl group, whereas another band in the range $1670-1678 \mathrm{~cm}^{-1}$ was seen due to the amidic carbonyl group. The ${ }^{1} \mathrm{H}$ NMR spectrum displayed a shift for the thiazole proton at $\delta 8.05-$ 8.10 and a multiplet signal in the region $\delta 7.10$ 7.90 due to the aromatic and the two olefinic pro- tons $\mathrm{CH}=\mathrm{CH}$. The reaction of aldehydes $\mathbf{7 a}-\mathbf{c}$ with the appropriate 5-arylazo-2-aminothiazole starting compound 3 (2:1) under the same reaction conditions led to the formation of the chalcone-imine derivatives 9a-c (Scheme 4), where the electrophilic carbon atoms of aldehydes $\mathbf{7 a - c}$ can be targeted by nucleophilic attack of the amines. As a result, the compound in which the $\mathrm{C}=\mathrm{O}$ double bond is replaced by a $\mathrm{C}=\mathrm{N}$ double bond was formed. This type of compound is known as an imine, or Schiff base.

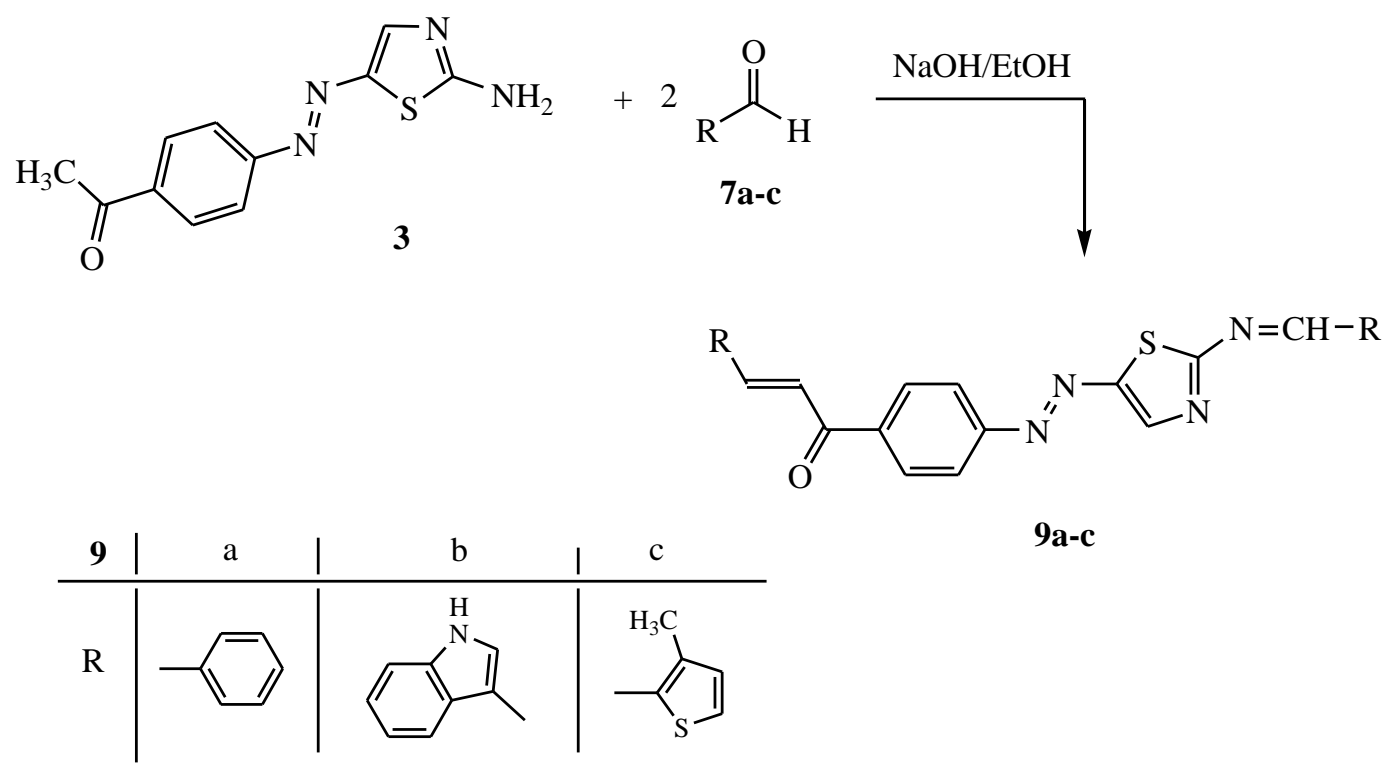

Scheme 4. Reaction of 5-arylazo-2-aminothiazole $\mathbf{3}$ with aldehydes $\mathbf{7 a - c}(1: 2)$ to form the chalcone-imine derivatives $\mathbf{9 a - c}$ 
Mechanistically, the formation of an imine is analogous to hemiacetal and hemiketal formation, and involves two steps. First, the amine's nitrogen acts as a nucleophile, attacking the carbonyl carbon [24]. The next step might be expected that the carbonyl carbon was attacked by a second amine to form a compound with a carbon bound to two amine groups (the nitrogen version of a ketal). Instead, the nitrogen is deprotonated, and the electrons from this $\mathrm{N}-\mathrm{H}$ bond 'push' the oxygen off of the carbon, leaving a $\mathrm{C}=\mathrm{N}$ double bond (an imine) and a displaced water molecule, as shown in Figure 1.

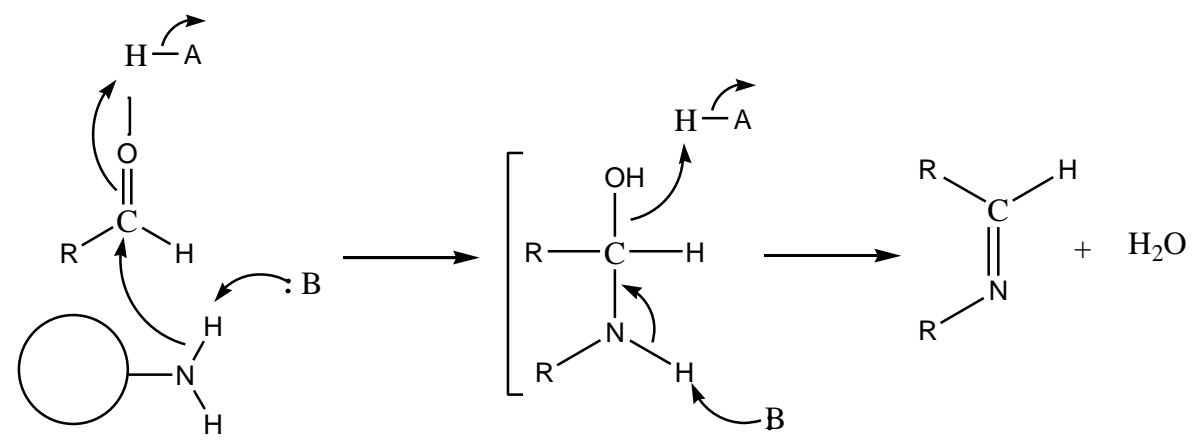

Fig. 1. Mechanism of imine formation

The chemical structures of 3-aryl(heteroaryl)-1-\{4-[(2-\{[aryl(heteryl)-methylidene $]$ amino $\}-$ 1,3-thiazol-5-yl)diazenyl]phenyl $\}$-prop-2-en-1-one derivatives $9 \mathbf{9}-\mathbf{c}$ were confirmed by their analytical and spectral data. A band in the range of 1655$1661 \mathrm{~cm}^{-1}$ due to the acetyl group was investigated, while the ${ }^{1} \mathrm{H}$ NMR spectrum displayed a singlet signal at $\delta 8.05$ due to the thiazole proton, and a multiplet signal in the region $\delta 7.10-7.90$ due to the aromatic protons and the two olefinic protons $\mathrm{CH}=\mathrm{CH}$.

Further reaction of $\alpha, \beta$-unsaturated carbonyl derivatives $\mathbf{8 a}-\mathbf{c}$ with hydrazine hydrate, proceed- ing throughout the hydrazide intermediate and subsequent dehydrogenation, yielded the pyrazole derivatives 10a-c (Scheme 5) [22]. The chemical structures of $N$-(5-\{(E)-[4-(5-phenyl-4,5-dihydro1H-pyrazol-3-yl)phenyl]diazenyl \}-1,3-thiazol-2-yl) acetamide 10a-c were confirmed by analytical and spectral data. The IR spectrum revealed sharp bands in the range $1675-1668 \mathrm{~cm}^{-1}$ due to the amidic carbonyl group, and $1635-1645 \mathrm{~cm}^{-1}$ due to the pyrazole $\mathrm{CH}=\mathrm{N}$, whereas the ${ }^{1} \mathrm{H}$ NMR spectrum exhibited a singlet signal at $\delta 8.10$ due to the thiazole proton and a multiplet signal in the region $\delta 7.10-7.80$ due to the aromatic protons.<smiles>[R]C=CC(=O)c1ccc(N=Nc2cnc(NC(C)=O)s2)cc1</smiles>

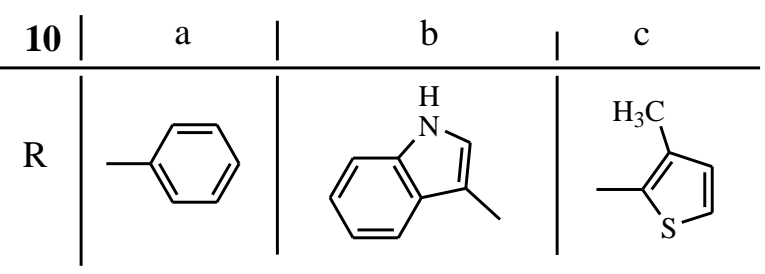

10a-c

Scheme 5. Reaction of $\alpha, \beta$-unsaturated carbonyl derivatives $\mathbf{8 a - c}$ with hydrazine hydrate to form the pyrazole derivatives 10a-c 


\subsection{Biological assessments}

In the present study, several monoazo $\mathrm{S} / \mathrm{N}$ heterocyclic compounds (3-6, 8a-c - 10a-c) were evaluated for toxicity and antioxidant activity. Firstly, antioxidant activities of the synthesized compounds were screened in vitro using the DPPH assay. Toxicity of the selected compounds based on in vitro antioxidant results was monitored in an animal model system, including the $\mathrm{LD}_{50}$ value, and GPT and LDH enzyme activities. In vivo antioxidant activities of the selected compounds $\mathbf{3 , 5 , 9 b}$, and $\mathbf{1 0 c}$, based on their in vitro antioxidant and toxicity results, were performed and also biochemical analyses, including SOD and GST enzymes and reduced glutathione (GSH-Rd) activities were evaluated.

\subsubsection{In vitro antioxidant activity of synthesized compounds}

Antioxidant capacities for the synthesized compounds were screened using the DPPH radicalscavenging assay incorporating a metastable free radical that is capable of accepting hydrogen radicals from antioxidants in solution. The reaction between DPPH and antioxidant can be monitored by the decrease in absorbance of the colored free radical. Results of the inhibition of the DPPH radical by tested compounds are listed in Table 1 and plotted in Figure 2. The inhibition affects against DPPH were not noticeably changed by doubling the concentration, and were in the order $10 \mathbf{c}>\mathbf{9 b}>$ $5>3$. This may be due to the presence of thiazole, pyrazole, and thiophene rings in the same compound 10c and fewer rings in the others.

Table 1

Antioxidant activity (\%) of the synthesized compounds 3-6 and 9a-c-10a-c at different concentrations using the DPPH free radical method

\begin{tabular}{ccc}
\hline \multirow{2}{*}{ Compound \# } & \multicolumn{2}{c}{ \% Antioxidant activity } \\
\cline { 2 - 3 } & $50 \mathrm{mg}$ & $100 \mathrm{mg}$ \\
\hline Trolox & 91.21 & 90.81 \\
(Control) & 45 & 46.9 \\
\hline 3 & 32.8 & 54.6 \\
4 & 66.8 & 71.3 \\
5 & 42.6 & 39.43 \\
6 & 37.9 & 33.9 \\
$9 \mathrm{a}$ & 40.1 & 42 \\
$9 \mathrm{~b}$ & 31.6 & 34.8 \\
$9 \mathrm{c}$ & 27.9 & 30.2 \\
$10 \mathrm{a}$ & 72.87 & 78.4 \\
$10 \mathrm{~b}$ & 38.9 & 40.5 \\
$10 \mathrm{c}$ & & \\
\hline \hline
\end{tabular}

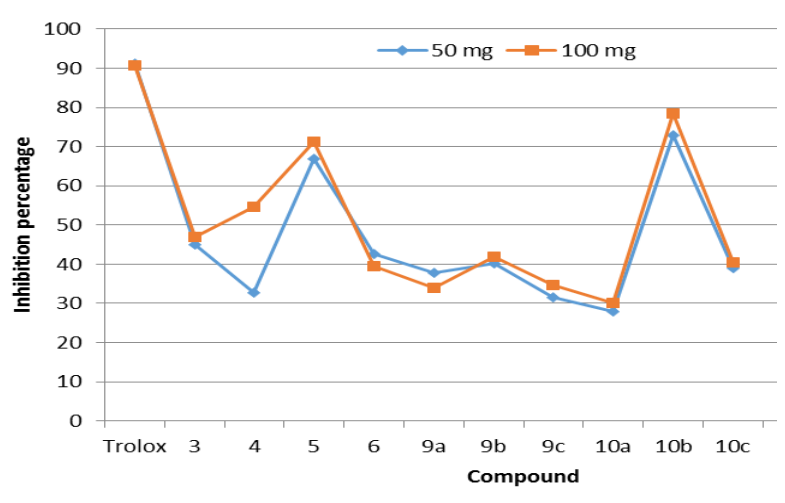

Fig. 2. Inhibition percentage of DPPH free radical by the synthesized compounds 3-6 and 9a-c -10a-c at different concentrations

\subsubsection{Acute toxicity studies}

Acute toxicity of selected compounds $\mathbf{3 , 5}$, 9b, and 10c were monitored in an animal model system. Biochemical parameters, including $\mathrm{LD}_{50}$, and GPT (an enzyme that allows determination of the liver function as an indicator of liver cell damage) and LDH (an enzyme that is used as a marker of tissue breakdown) activities, were recorded during treatment with graded doses of $50-500 \mathrm{mg} / \mathrm{kg}$ body weight of each selected synthesized compound. Toxicity results showed that no mortality was observed during administration with the selected synthesized compounds up to $500 \mathrm{mg} / \mathrm{kg}$ body weight. The GPT and LDH enzyme activities are listed in Table 2 and plotted in Figure 3.There was no significant effect after administration with the selected synthesized compounds up to 500 $\mathrm{mg} / \mathrm{kg}$ body weight, which indicates that there was no toxicity of the synthesized compounds up to high concentrations.

\section{Table 2}

Effect of the selected synthesized compounds $3,5,9 b$ and $10 c$ on $L D H$ and GPT enzymes at different concentrations

\begin{tabular}{|c|c|c|c|c|c|}
\hline \multirow{2}{*}{ Compound } & \multicolumn{5}{|c|}{$\begin{array}{c}\text { Enzymes activity } \\
\text { units/liter of blood serum }\end{array}$} \\
\hline & $\begin{array}{l}50 \\
\mathrm{mg}\end{array}$ & $100 \mathrm{mg}$ & $200 \mathrm{mg}$ & $300 \mathrm{mg}$ & $500 \mathrm{mg}$ \\
\hline 3-LDH & 25 & 32 & 34 & 29 & 36 \\
\hline 3- GPT & 45 & 43 & 35 & 40 & 41 \\
\hline 5-LDH & 27 & 30 & 35 & 37 & 28 \\
\hline 5-GPT & 42 & 41 & 46 & 44 & 41 \\
\hline 9b-LDH & 22 & 21 & 24 & 26 & 25 \\
\hline 9b-GPT & 40 & 35 & 38 & 32 & 36 \\
\hline $10 \mathrm{c}-\mathrm{LDH}$ & 20 & 21 & 24 & 19 & 18 \\
\hline 10c-GPT & 39 & 41 & 42 & 43 & 40 \\
\hline
\end{tabular}




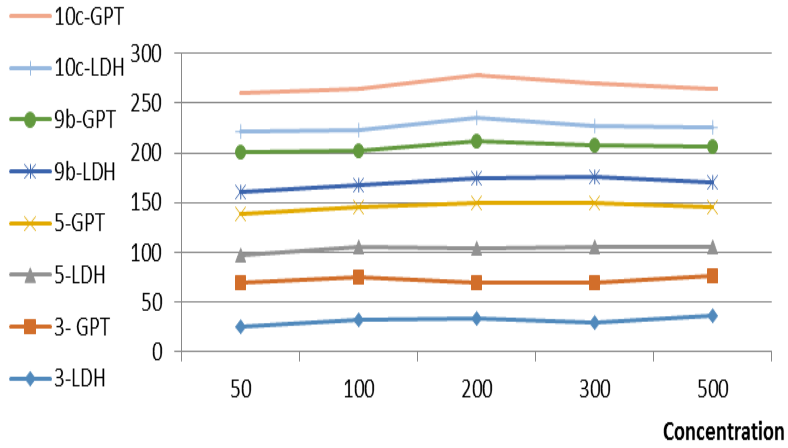

Fig. 3. Effect of different compounds on LDH and GPT enzymes

\subsubsection{In vivo antioxidant activity}

SOD, GST, and GSH-Rd levels were measured in vivo to monitor the antioxidant activities, and are listed in Table 3. SOD and GST are antioxidant enzymes that protect cells from oxidative stress of highly reactive free radicals formed in normal conditions (food metabolites) or abnormal conditions (presence of environment pollutants) [25]. These enzymes are induced by the generation of free radicals in cells.

T a ble 3

Effect of compounds $3,5,9 b$ and $10 c$ on SOD, GST, and GSH-Rd in control, vitamin E and treated rat groups

\begin{tabular}{lccc}
\hline \hline \multicolumn{1}{c}{$\begin{array}{c}\text { Treatment } \\
\text { compound \# }\end{array}$} & $\begin{array}{c}\text { SOD } \\
(\text { Units/mg protein) }\end{array}$ & $\begin{array}{c}\text { GST } \\
\mu \text { mol/mg protein }\end{array}$ & $\begin{array}{c}\text { GSH-Rd } \\
(\mathrm{mg} / \mathrm{g} \text { protein })\end{array}$ \\
\hline Normal control (Group 1) & $12.15 \pm 0.14^{\mathrm{b}}$ & $3.32 \pm 0.09^{\mathrm{b}}$ & $5.11 \pm 0.61^{\mathrm{b}}$ \\
Vitamin E (Group 2) & $15.35 \pm 0.43^{\mathrm{a}, \mathrm{b}}$ & $5.12 \pm 0.25^{\mathrm{a}, \mathrm{b}}$ & $7.41 \pm 0.43^{\mathrm{a}, \mathrm{b}}$ \\
$3(50 \mathrm{mg} / \mathrm{kg}$; Group 3) & $11.21 \pm 0.11^{\mathrm{a}, \mathrm{b}}$ & $3.90 \pm 0.19^{\mathrm{a}, \mathrm{b}}$ & $6.34 \pm 0.22^{\mathrm{a}, \mathrm{b}}$ \\
$3(100 \mathrm{mg} / \mathrm{kg}$; Group 4) & $10.61 \pm 0.73^{\mathrm{a}, \mathrm{b}}$ & $3.15 \pm 0.11^{\mathrm{a}, \mathrm{b}}$ & $5.81 \pm 0.61^{\mathrm{a}, \mathrm{b}}$ \\
$5(50 \mathrm{mg} / \mathrm{kg}$; Group 5) & $11.02 \pm 0.52^{\mathrm{a}, \mathrm{b}}$ & $2.89 \pm 0.15^{\mathrm{a}, \mathrm{b}}$ & $5.04 \pm 0.31^{\mathrm{a}, \mathrm{b}}$ \\
$5(100 \mathrm{mg} / \mathrm{kg}$; Group 6) & $10.76 \pm 0.13^{\mathrm{a}, \mathrm{b}}$ & $2.91 \pm 0.07^{\mathrm{a}, \mathrm{b}}$ & $4.74 \pm 0.21^{\mathrm{a}, \mathrm{b}}$ \\
9b (50mg/kg; Group 7) & $11.02 \pm 0.17^{\mathrm{a}, \mathrm{b}}$ & $1.87 \pm 0.09^{\mathrm{a}, \mathrm{b}}$ & $5.34 \pm 0.41^{\mathrm{a}, \mathrm{b}}$ \\
9b (100mg/kg; Group 8) & $11.21 \pm 0.19^{\mathrm{a}, \mathrm{b}}$ & $1.95 \pm 0.15^{\mathrm{a}, \mathrm{b}}$ & $5.67 \pm 0.54^{\mathrm{a}, \mathrm{b}}$ \\
10c (50mg/kg; Group 9) & $13.48 \pm 0.42^{\mathrm{a}}$ & $4.91 \pm 0.70^{\mathrm{a}}$ & $5.82 \pm 0.32^{\mathrm{a}}$ \\
$10 \mathrm{c}(100 \mathrm{mg} / \mathrm{kg}$; Group10) & $13.97 \pm 0.29^{\mathrm{a}}$ & $4.25 \pm 0.15^{\mathrm{a}}$ & $5.70 \pm 0.63^{\mathrm{a}}$ \\
\hline \hline
\end{tabular}

Values are mean $\pm \mathrm{SD}, n=6$.

a: $p<0.05$ compared with vehicle control group.

b: $p<0.05$ compared with vitamin E group.

$n$ : number of rats in each group.

There were significant increases $(p<0.05)$ in SOD and GST activities in the 10c treated groups at doses of 50 and $100 \mathrm{mg} / \mathrm{kg}$ compared to the control (untreated) group ( $p<0.05$ ) and nearly matched the treated group with vitamin $\mathrm{E}$ as standard antioxidant. No significant differences were observed between the doses (50 and $100 \mathrm{mg} / \mathrm{kg}$ ) with any tested compound.

\section{CONCLUSIONS}

A new 2-amino-5-(4-acetylphenylazo)-thiazole was synthesized, and the reactivity of both the amino group and the aryl substituent via various active carbonyl reagents and custom chemical reactions yielded new bioactive chalcone, imine, and pyrazole derivatives. The synthesized derivatives were structurally confirmed and biologically screened in vitro and in vivo for their toxicity and antioxidant activity. The synthesized compounds showed a noticeable inhibition effect against DPPH and significant increases in antioxidant enzyme activities in the treated rats groups at doses of 50 and $100 \mathrm{mg} / \mathrm{kg}$ compared to the control group ( $p<$ $0.05)$. In addition, the synthesized compounds showed no significant toxicity at high concentrations based on liver function enzyme evaluation.

Acknowledgments. The authors would like to extend their thanks to the staff of the Chemistry Department, Faculty of Science, Taif University, KSA, for their technical support.

\section{REFERENCES}

[1] P. C. Hang, J. F. Honek, Electronic structure calculations on the thiazole-containing antibiotic thiostrepton: molecular mechanics, semi-empirical and ab initio analyses, Bioorg. Med. Chem. Lett., 15, 1471-1474 (2005).

[2] A. Geronikaki, P. Vicini, N. Dabarakis, A. Lagunin, V. Poroikov, J. Dearden, H. Modarresi, M. Hewitt, G. 
Theophilidis, Evaluation of the local anaesthetic activity of 3-aminobenzo $[d]$ isothiazole derivatives using the rat sciatic nerve model, Eur. J. Med. Chem., 44, 473-481 (2009).

[3] C. Papadopoulou, A. Geronikaki, D. Hadjipavlou-Litina, Synthesis and biological evaluation of new thiazolyl/benzothiazolyl-amides, derivatives of 4phenyl-piperazine, II Farmaco, 60, 969-973 (2005).

[4] A. Kreutzberger, H. Schimmelpfennig, Antiviral drugs, XVIII: 2-Aminothiazoles by cleavage of the S-S-bond of disulfidodicarbamidine, Arch. Pharm., 314, 385-391 (1981).

[5] E. Abdel-Latif, M. A. Metwally, F. A. Amer, M. E. Khalifa, Synthesis of 5-arylazo-2-(arylidenehydrazino)thiazole disperse dyes for dyeing polyester fibres, Pigm. Resin. Technol., 38, 105-110 (2009).

[6] M. A. Metwally, M. E. Khalifa, E. Abdel-Latif, F. A. Amer, New arylhydrazonothiazolidin-5-one disperse dyes for dyeing polyester fibers, Pol. J. Chem. Technol., 12, 1-6 (2010).

[7] M. E. Khalifa, M. A. Metwally, E. Abdel-Latif, F. A. Amer, Synthesis of Some New 5-Arylazothiazole Derivatives as Disperse Dyes for Dyeing Polyester Fibers. Inter. J. Textile Science, 1, 62-68 (2012).

[8] M. E. Khalifa, E. Abdel-Latif, A. A. Gobouri, Disperse Dyes Based on 5-Arylazo-thiazol-2-ylcarbamoylthiophenes: Synthesis, Antimicrobial Activity and Their Application on Polyester, J. Heterocycl. Chem., 52, 674-680, (2015).

[9] A. Göblyös, S. N. Santiago, D. Pietra, T. MulderKrieger, J. F. D. Künzel, J. Brussee, A. P. Ijzerman, Synthesis and biological evaluation of 2-aminothiazoles and their amide derivatives on human adenosine receptors. Lack of effect of 2-aminothiazoles as allosteric enhancers, Bioorg. Med. Chem., 13, 2079-2087 (2005).

[10] P. Beuchet, M. Varache-Lembège, A. Neveu, J. M. Léger, J. Vercauteren, S. Larrouture, G. Deffieux, A. Nuhrich, New 2-sulfonamidothiazoles substituted at C4: synthesis of polyoxygenated aryl derivatives and in vitro evaluation of antifungal activity, Eur. J. Med. Chem., 34, 773-779 (1999).

[11] A. Geronikaki, G. Theophilidis, Synthesis of 2(aminoacetylamino)thiazole derivatives and comparison of their local anaesthetic activity by the method of action potential, Eur. J. Med. Chem., 27, 709-716 (1992).

[12] P. Molyneux, The use of the stable free radical diphenylpicrylhydrazyl (DPPH) for estimating antioxidant activity, Songklanakarin J. Sci. Technol., 26, 211219 (2004)
[13] OECD Guideline for the testing of chemicals. Acute oral toxicity - acute toxic class method: Test no-423. Organization for Economic Co-operation and Development.

[14] S. Daniel, M. D. Pratt, M. Marshall, M. D. Kaplan, Evaluation of Abnormal Liver-Enzyme Results in Asymptomatic Patients, Engl. J. Med., 342, 1266-1271 (2000).

[15] E. Amador, L. E. Dorfman, W. E. C. Wacker, Serum Lactic Dehydrogenase Activity: An Analytical Assessment of Current Assays, Clin. Chem., 9, 391-399 (1963).

[16] W. H. Habig, M. J. Pabst, W. B. Jakoby, Glutathione Stransferase AA from rat liver, Arch. of Biochem. and Biophy., 175, 710-716 (1976).

[17] Y. Zeng, Y. Ren, Density functional theory study of tautomerization of 2-aminothiazole in the gas phase and in solution, Inter. J. Quantum Chem., 107, 247-258 (2007).

[18] M. Nishikimi, N. A. Roa, K. Yogi, The occurrence of superoxide anion in the reaction of reduced phenazine methosulfate and molecular oxygen, Biochem. Bioph. Res. Common., 46, 849-854 (1972).

[19] G. L. Ellman, A colorimetric method for determining low concentrations of mercaptans. Arch. Biochem. Biophys., 74, 443-450(1958).

[20] M. M. Bradford, A rapid and sensitive method for the quantitation of microgram quantities of protein utilizing the principle of protein-dye binding, Anal. Biochem., 72, 248-254 (1976).

[21] L. Claisen, A. Claparède, Condensationen von Ketonen mit Aldehyden, Ber. Dtsch. Chem. Ges. 14, 2460-2468 (1881).

[22] J. G. Schmidt, Ueber die Einwirkung von Aceton auf Furfurol und auf Bittermandelöl in Gegenwart von Alkalilauge, Ber. Dtsch. Chem. Ges., 14, 1459-1461 (1881).

[23] J. March, Advanced Organic Chemistry: Reactions, Mechanisms and Structure, $3^{\text {rd }}$ edn. Wiley, New York, USA, 1985.

[24] T. Soderberg, Organic Chemistry with a Biological Emphasis, Chapter 11: Nucleophilic carbonyl addition reactions, Section 11.6: Imine (Schiff base) formation. http://chemwiki.ucdavis.edu/.

[25] M. Valko, C. J. Rhodes, J. Moncol, M. Izakovic, M. Mazur, Free radicals, metals and antioxidants in oxidative stress-induced cancer, Chemico.Biological Interactions, 160, 1-40 (2006). 